\title{
歯周外科手術後の治癒に対する喫煙の影響について
}

\author{
大森みさき川俣 晴海金谷一彦 \\ 廣木祐子長谷川 明 \\ 日本歯科大学新潟歯学部歯周治療学教室 \\ （主任：長谷川 明教授） \\ (平成 9 年 8 月 11 日受付)
}

\section{The Effect of Smoking on Healing after Periodontal Surgery}

Misaki Ohmori, Harumi Kawamata, Kazuhiko Kanaya, Yuko Hiroki and Akira Hasegawa

Department of Periodontics, The Nippon Dental University, School of Dentistry at Niigata

1-8 Hamauracho Niigata, 951 Japan

(Chief : Prof. Akira Hasegawa)

The purpose of this study was to compare the clinical effects of surgical therapy in smokers and non-smokers.

Fifty-Seven patients (age range 27 66 years, average 49.9 years), 32 men and 25 women, were investigated.

Twenty five of the patients were smokers and 32 were non-smokers. The patients had moderate to severe periodontitis with persistent diseased sites (probing depth $4 \mathrm{~mm}$ or more) after non-surgical therapy. The surgical modalities used were the modified Widman flap operation or the apically repositioned flap operation.

Re-examination was done 2 months or more after surgery.

The oral hygiene status and gingival bleeding index were similar in the two groups. No differences were observed regarding probing depths except for palatal pockets of the maxilla where a significantly greater probing depth was observed in smokers $(\mathrm{P}<0.05)$.

The results suggest that smoking may impair the outcome of surgical therapy.

Key words : Smoking, Periodontal surgery, Marginal periodontitis, Periodontal pocket

要旨：歯周外科的処置後の治癒に対する喫煙の影響を検討するために初期治療後に残存する歯周ポケットの改 善を目的として歯周外科手術を行った患者を喫煙習慣の有無で分け，術前，術後の歯周ポケットの深さの変化を 調査した。対象は歯周外科手術を行った患者 57 名（男性 32 名，女性 25 名，27〜66 歳，平均 49.9 歳）で，契 煙者は 25 名, 非喫煙者は 32 名であった。被験部位は手術前に $4 \mathrm{~mm}$ 以上のポケットを認めた 414 部位とした。 手術はWidman 改良法または歯肉弃根尖側移動術によって行った。術後の再評価は 2 力月後以降に行った。

手術前後で喫煙者/非喫煙者間に Probing Depth (PD), Gingival Bleeding Index (GBI), Plaque Control Record（PCR）に差異はみられなかったが，PD を部位別に検討した結果，契煙者の上顎口蓋側の PDの改善が 非喫煙者に比べ有意に少なかった $(\mathrm{P}<0.05)$ 。

これらの結果より喫煙の影響によって歯周外科手術後に上顎口蓋側の治癒が阻害される可能性が示唆された。

索引用語：喫煙，歯周外科手術，辺縁性歯周炎，歯周ポケット 


\section{緒 言}

喫煙が歯周疾患のリスクファクターであり，また， 非外科的処置, 外科的処置ともに治癒を阻害すると言 われているが，わが国ではその臨床的報告はあまりな されていない。私達はこれまでに初診時の男性患者で は喫煙者の方が非喫煙者より歯周疾患が重度であるこ と ${ }^{1)}$ ，歯周外科手術時に採取した歯肉組織を観察した 結果，契煙者の方が歯肉上皮内への炎症性細胞浸潤が 強いこと 2)を報告してきた。本研究では歯周外科手術 後の治瘉に対する喫煙の影響を検討することを目的と して術後ひ経過を追跡した。すなわち，初期治療（ス ケーリング・ルートプレーニング) 後に歯周ポケット の除去を目的として歯周外科手術を行った患者を喫煙 の有無で分け, 術前, 術後の歯周ポケット深さの変化 を調査し検討を試みた。

\section{材料および方法}

\section{1. 被験者および被験歯}

日本歯科大学新潟歯学部附属病院歯周治療科におい て慢性辺縁性歯周炎と診断され, 初期治療（スケーリ ング・ルートプレーニング）終了後に残存する深いポ ケットの改善を目的とする歯周外科手術を行った患者 57 名（男性 32 名，女性 25 名，27～66 歳, 平均 49.9 歳）を対象とした。そのうち喫煙者は 25 名（男性 17 名, 女性 8 名, 平均 46.0 歳), 非喫煙者は 32 名（男 性 15 名，女性 17 名，平均 52.4 歳）であった。喫煙 者は喫煙本数が 1 日 10〜 40 本 (平均 23.9 本), 喫煙 年数が 10〜 40 年（平均 23.9 年）であった。なお，歯 周外科手術はWidman 改良法または歯肉弁根尖側移 動術によって行った。

調查対象は各被験者において歯周外科手術前に 4 $\mathrm{mm}$ 以上のポケットを認めた 414 部位とした。今回 手術対象となった歯種の内訳は表 1 に示す通りであ る。

\section{2. 臨床検査}

手術後の再評価は 2 力月後以降に行われた。初期治

表 1 被験部位

\begin{tabular}{ccccccccc|c}
\hline 歯種 & 1 & 2 & 3 & 4 & 5 & 6 & 7 & 8 & 計 \\
\hline 上頢 & 20 & 9 & 25 & 35 & 37 & 33 & 30 & 6 & 195 \\
下顗 & 27 & 33 & 20 & 20 & 25 & 52 & 40 & 2 & 219 \\
\hline 計 & 47 & 42 & 45 & 55 & 62 & 85 & 70 & 8 & 414 \\
\hline
\end{tabular}

療後と手術後の再評価時に以下の項目について診査を 行った。

1) Probing Depth (以下 PD)

日本歯科大学新潟歯学部式プローベ3)を使用し, 約 $25 \mathrm{~g}$ の圧をかけ煩側 3 点（近心，中央，遠心)，舌側 3 点（近心, 中央, 遠心）の各歯 6 点について 1 $\mathrm{mm}$ 単位で測定した。

2) Gingival Bleeding Index (以下 GBI)

Ainamo and Bay の方法 ${ }^{4} に$ 準じて記録した。

3) Plaque Control Record (以下 PCR)

$\mathrm{O}^{\prime}$ Leary $^{5)}$ らの方法に準じ 1 歯 6 点で記録した。

\section{3. 統計処理}

喫煙者と非喫煙者との群間比較にはMannWhitney のU 検定，契煙者，非喫煙者それぞれの術 前術後の群内比較には Wilcoxon 検定を用いて検討し た。

\section{結 果}

術前，術後の診査結果は表 $2 \sim 4$ に示した通りであ る。術前, 術後とも PCR, GBI に喫煙者/非喫煙者 間に有意な差は認められず, 喫煙者の術前, 術後の群 内比較でも有意差は認められなかった。非喫煙者では GBI の術前, 術後の群内比較において有意な減少が 認められた $(\mathrm{P}<0.05)$ 。

$\mathrm{PD}$ は喫煙者/非喫煙者とも術前, 術後の群内比較 において有意な改善が認められた $(\mathrm{P}<0.001)$ が, 両群間に有意な差は認められなかった。

表 5 に部位別の PD の変化を示した。いずれの部位 でも術前，術後の群内比較において術後に有意な改善 が認められた $(\mathrm{P}<0.001)$ 。上顎口蓋側の術前の PD は喫煙者が $5.1 \pm 1.0 \mathrm{~mm}$, 非喫煙者では $5.5 \pm 1.7$ $\mathrm{mm}$ で両群間に差が見られないのに対して, 術後で は喫煙者が $3.0 \pm 0.9 \mathrm{~mm}$ ，非喫煙者が $2.7 \pm 0.7 \mathrm{~mm}$ で両群間に有意差が認められた $(\mathrm{P}<0.05)$ 。しかし ながら，上顎煩側，下顎煩舌側ではいずれも両群間に 有意な差は認められなかった。

表 6 に歯周外科手術による治療効果の比較を示し

表 2 PCR（\%) の経過

\begin{tabular}{|c|c|c|c|}
\hline & 喫煙者 (25 名) & 非喫煙者 (32 名) & $\mathrm{P}$ \\
\hline & mean \pm S.D. & mean \pm S.D. & \\
\hline $\begin{array}{l}\text { 術前 } \\
\text { 術後 }\end{array}$ & $\left.\begin{array}{l}13.8 \pm 7.9 \\
18.7 \pm 13.6\end{array}\right]$ N.S. & $\left.\begin{array}{l}14.4 \pm 13.8 \\
15.7 \pm 14.5\end{array}\right]$ N.S. & $\begin{array}{l}\text { n.s. } \\
\text { n.s. }\end{array}$ \\
\hline
\end{tabular}

$\mathrm{P}$ : Mann-Whitney のU検定（n.s.：有意差なし）

N.S.：有意差なし（Wilcoxon 検定） 
表 3 GBI（\%）の経過

\begin{tabular}{|c|c|c|c|}
\hline & 喫煙者 (25 名) & 非喫煙者 (32 名) & $\mathrm{P}$ \\
\hline & mean \pm S.D. & mean \pm S.D. & \\
\hline $\begin{array}{l}\text { 術前 } \\
\text { 術後 }\end{array}$ & $\left.\begin{array}{l}12.9 \pm 10.4 \\
10.7 \pm 12.1\end{array}\right]$ N.S. & $\left.\begin{array}{r}15.0 \pm 9.8 \\
8.9 \pm 7.0\end{array}\right] *$ & $\begin{array}{l}\text { n.s. } \\
\text { n.s. }\end{array}$ \\
\hline
\end{tabular}

P : Mann-Whitney のU検定 (n.s. : 有意差なし)

N.S. : 有意差なし, ${ }^{*}: \mathrm{p}<0.05$ (Wilcoxon 検定)

表 5 部位別の PD の変化 $(\mathrm{mm})$

\begin{tabular}{|c|c|c|c|}
\hline & & 喫煙者 (25 名) & 非喫煙者 (32 名) \\
\hline \multirow{3}{*}{ 上顎煩側 } & & mean \pm S.D. & mean \pm S.D. \\
\hline & • 術前 & $5.0 \pm 0.9$ & $5.2 \pm 1.6$ \\
\hline & - 術後 & $2.6 \pm 1.1$ & $2.8 \pm 0.9$ \\
\hline \multirow[t]{2}{*}{ 上顎口蓋側 } & • 術前 & $5.1 \pm 1.0$ & $5.5 \pm 1.7$ \\
\hline & • 術後 & $3.0 \pm 0.9=$ & $-2.8 \pm 0.9$ \\
\hline \multirow[t]{2}{*}{ 下顎煩側 } & • 術前 & $5.9 \pm 1.4$ & $5.6 \pm 1.8$ \\
\hline & • 術後 & $2.6 \pm 1.2-$ & $2.5 \pm 1.0$ \\
\hline \multirow[t]{2}{*}{ 下顎舌側 } & • 術前 & $5.5 \pm 1.5$ & $5.4 \pm 1.47 *$ \\
\hline & • 術後 & $2.4 \pm 1.2-$ & $2.4 \pm 1.0$ \\
\hline
\end{tabular}

\# : p $<0.05$ (Mann-Whitney のU検定)

***: $\mathrm{p}<0.001$ (Wilcoxon 検定)

表 7 改善不良群の内訳

\begin{tabular}{ccc|c}
\hline & 喫煙者 & 非喫煙者 & 計 \\
\hline 上顎煩側 & 6 & 4 & 10 \\
上顎口蓋側 & 14 & 5 & 19 \\
下顎煩側 & 6 & 10 & 15 \\
下顎舌側 & 9 & 8 & 17 \\
\hline 計 & 35 & 27 & 62 \\
\hline
\end{tabular}

た。術後に PD が $3 \mathrm{~mm}$ 以下の良好な改善が見られた のは喫煙者の $82.6 \%$, 非契煙者の $87.3 \%$, 術前より 浅くなったものの依然 $4 \mathrm{~mm}$ 以上の PD を認める改善 が不良な部位は喫煙者の $11.4 \%$, 非契煙者の $9.9 \%$, 全く改善がみられなかったのは喫煙者の $6.0 \%$, 非喫 煙者の $2.8 \%$ であった。契煙者の方がやや改善が悪い 傾向がみられた。

表 7 に術後の改善が不良もしくは改善が見られな かった部位の内訳を示した。 414 部位中 62 部位で全 体の $15.0 \%$ であった。そのうち喫煙者は 35 部位, 非 喫煙者は 27 部位であった。部位別では上顎口蓋側が 一番多く 19 部位でそのうち喫煙者は 14 部位で $73.7 \%$ を占めた。
表 4 PD (mm) の経過

\begin{tabular}{|c|c|c|c|}
\hline & 喫煙者 (25 名) & 非喫煙者 (32 名) & $\mathrm{P}$ \\
\hline & mean \pm S.D. & mean \pm S.D. & \\
\hline 術前 & $5.3 \pm 1.27$ & $5.5 \pm 1.6$ & n.s. \\
\hline 術後 & $2.7 \pm 1.1$ & $2.6 \pm 0.9$ & n.s. \\
\hline
\end{tabular}

$\mathrm{P}$ : Mann-Whitney のU 検定（n.s.：有意差なし）

**: $\mathrm{p}<0.05$ (Wilcoxon 検定)

表 6 治療効果の比較

\begin{tabular}{ccc}
\hline & 喫煙者 & 非喫煙者 \\
\hline 改善良好群 & $82.6 \%(166 / 201)$ & $87.3 \%(186 / 213)$ \\
改善不良群 & $11.4 \%(23 / 201)$ & $9.9 \%(21 / 213)$ \\
非改善群 & $6.0 \%(12 / 201)$ & $2.8 \%(6 / 213)$ \\
\hline
\end{tabular}

\section{考察}

近年, 歯周外科手術の目的は深い歯周ポケットの除 去から歯根面への器具の到達が不十分な部位に対し明 視下で適正な器具操作を行うこと, また炎症の進展を うながすような歯肉や骨の異常を修正することへと変 わってきている6)。しかし実際には病変が進行しすぎ て非外科療法では治癒が望めない場合が歯周外科手術 の最適応である。本研究では研究対象を初期治療（又 ケーリング・ルートプレーニング）で改善が見られな かった $4 \mathrm{~mm}$ 以上の歯周ポケットにした。この理由 は日本歯科大学新潟歯学部歯周治療科では歯周ポケッ 卜の深さ $4 \mathrm{~mm}$ を手術適応の一つの指標としている ためである。これは歯肉緑下 $3 \mathrm{~mm}$ を越える根面で はプラークとその産生物の完全な除去は困難であると いう Waehaug の報告7,8), 歯周ポケットが $4 \mathrm{~mm}$ を越 えると完全な歯肉縁下のプラークおよび歯石の除去は 困難であるという報告 ${ }^{911)}$ な゙゙に基づいている。

歯周外科手術を行った結果歯周ポケットは減少する と過去の研究では一致した見解を示している ${ }^{10,11)}$ 。し かしながら, 喫煙者では非喫煙者に比べこれらの手術 後の経過が悪いことが示唆されている12)。また, ア タッチメントレベルの獲得が少ないという報告もあ る ${ }^{13)}$ 。本研究では対象者を喫煙の有無で分け, $4 \mathrm{~mm}$ 以上の PD について術前, 術後での PD の変化を比較 検討した。また，全顎の PCR，GBI の推移も同時に 比較した。

喫煙とプラークの関係については様々な報告があ $\eta^{14 \sim 16)}$, 初期の研究では喫煙者ではプラークの付着

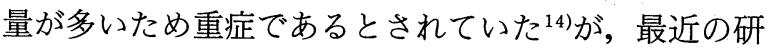


究では同程度かむしろ少ないとされている ${ }^{15,16)}$ 。本研 究では初期治療後のため喫煙者/非喫煙者ともプラー クコントロールは良好で, 術前, 術後の PCR, GBI とも喫煙者/非喫煙者間で有意差を認めなかった。非 喫煙者の GBI は術前に比べ術後に有意な改善を認め たが，喫煙者では変化が認められなかった。これらの 結果はプラーク付着量に関わらず，非喫煙者に比べて 喫煙者では手術後の炎症の改善が良くないことを示唆 するものと考える。喫煙者では歯肉出血が重症度に比 例せず非喫煙者に比べ少ないことが指摘されている が1)，本研究の対象者では初期治療後の GBI に違いは みられなかった。非外科治療への反応については今回 検討を行っていないが，手術前の状態は喫煙者/非喫 煙者間で違いはなかったものと考える。

手術後の喫煙者の GBI に改善がみられなかったの は歯周外科手術時に採取した歯肉組織を観察した結 果, 喫煙者の方が歯肉上皮内への炎症性細胞浸潤が強 かったこと とも関連し, 歯周ポケット内の炎症の改 善が良くなく創傷治癒が遅延しているのではないかと 考える。

鴨井ら ${ }^{17)}$ の報告では強制喫煙させたラットのフラッ プ手術後の治癒は喫煙していない対照群より遅延して いる状態が見られたとされている。また，歯周組織の 線維芽細胞が低濃度のニコチンを貯蔵したり放出した

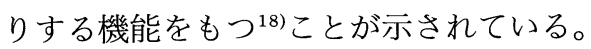

ニコチンに影響された線維芽細胞の付着能力に及ぼ す影響については明確ではない ${ }^{19,20)}$ が，ニコチンが歯 肉線維芽細胞の増殖を抑制し, フィブロネクチンとコ ラーゲンの産生を抑制し，コラーゲンの破壊を促進す るという結果が示されている ${ }^{21)}$ 。このた喫煙者の歯 周組織の修復と再生に影響を及ぼす可能性は大である と考える。

また，喫煙時に歯肉血流量が減少すること ${ }^{22)}$, ニコ チンを投与されたラットの歯肉毛細血管の長さ, 高さ

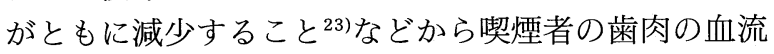
量が少ないことが予想され，これが治癒を阻害する可 能性も考えられる。

免疫学的観点からは喫煙者の口腔内の好中球やリン パ球の機能低下 ${ }^{24)}$, 唾液中のIgA などの抗休の減 少 ${ }^{25)}$ が報告されており組織抵抗力の低下も考慮に入れ る必要がある。

本研究では術前, 術後の PD は喫煙者, 非喫煙者そ れぞれの群内比較では有意な改善が認められたが, 喫 煙者/非喫煙者間では有意差を認めなかった。局所的 に検討した結果, 全ての部位の群内比較で術後の PD に改善が認められたが, 喫煙者/非喫煙者間では有意 差が認められたのは上顎口蓋側の術後のPD だけで
あった。これらの結果は喫煙者の歯槽骨吸収量は下顎

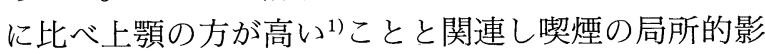
響を示唆するものと考える。

また，歯周外科手術後の治療効果を検討した結果， 喫煙者においても $82.6 \%$ は術後に PD が $3 \mathrm{~mm}$ 以下 に改善しており，非喫煙者の $87.3 \%$ に比べやや劣る ものの一定水準以上の治癒は得られたものと思われ る。そこで部位特異性を考慮し術後の PD の改善が不 良な 62 部位を検討した結果, 上顎口蓋側が 19 部位で 最も多く，そのうち喫煙者が $73.7 \%$ を占めた。この 結果は上顎口蓋側の術後の PD に両群間で有意差が認 められたことと合わせて，喫煙者の上顎口蓋側におい て治癒が良くないことを示唆するものと考える。この 理由としては喫煙によってロ腔内が陰圧になること や，その夕バコ自体を通過して口腔内に達する主流煙 が口蓋粘膜への強い刺激となるため, または他の部位 は舌や煩粘膜, 口唇などによる解剖学的形態から喫煙 の直接的影響を受けにくい可能性があることなどが考 えられる。

喫煙が関連した臨床的報告として口腔内小外科処置 の予後に関しては, 喫煙者は抜歯時のドライソケット 発生率が高いこと故，軟織のグラフトの失敗例が多 いこと ${ }^{27)}$, インプラントの失敗例が多いこと ${ }^{28)}$, GTR のアタッチメントの獲得が少ないこと年など創 傷治癒の反応が悪いことがいくつか報告されている。

これらの研究結果から喫煙者の歯周外科好置はある 程度のリスクがあることを考慮の上で慎重に行うべき であると思われる。また, 喫煙者の歯周外科処置に際 してできることなら禁煙または節煙を試み局所への歯 肉血流量の維持をはかるとか, 歯周包帯の期間を長く し創面への喫煙による污染物質の沈着を可及的に防止 するなど喫煙の創傷治癒に対する影響を少なくする方 法を検討する必要があるかもしれない。

\section{文献}

1）大森みさき：歯周疾患に対する喫煙の影響に関する 研究, 第 1 報 臨床的パラメー夕の分析, 歯学, $83: 748-755.1995$.

2）葛城啓彰, 大森みさき, 富井伸之, 岡村勝文, 長谷 川明, 斉藤和子 : 喫煙が重度歯周炎患者歯周組織に 及ぼす影響についての免疫組織化学的研究. 日歯周 誌, $39: 113-120,1997$.

3）浜口茂雄：歯間部歯周ポケットとその測定法に関す る研究. 日歯周誌, $31 ： 608-632,1989$.

4) Ainamo, J. and Bay, I. : Problems and proposals for recording gingivitis and plaque. Int. Dent. J., $25: 229-235,1975$. 
5) O'Leary, T.J., Dranke, R.B. and Naylor, J.E. : The plaque control record. J. Periodontol., 43 : 38, 1972.

6）長谷川明：日本における歯周外科手術, 歯学, 82 ： 755-767, 1994

7) Waehaug, J. : Subgingival plaque and loss of attachment in periodontosis as evaluated on extracted teeth. J. Periodontol., 48:125-130, 1977.

8) Waehaug, J. : Healing of the dentoepithelial junction following subgingival plaque control. J. Periodontol., 49 : 119-134, 1978.

9) Badersten, A., Nilveus, R. and Engelberg, J. : Effect of nonsurgical periodontal therapy. I. Moderately advanced periodontitis. J. Clin. Periodontol., $8: 57-72,1981$.

10) Hill, R.W., Ramfjord, S.P., Morrison, E.C., Appleberry, E.A., Caffesse, R.G., Kerry, G.J. and Nissle, R.R. : Four types of periodontal treatment compared over two years. J. Periodontol., 52 : 655-662, 1981.

11) Pihlstrom, B.L., Ortiz-Campos, C. and McHugh, R.B. : A randomized four-year study of periodontal therapy. J. Periodontol., 52:227-242, 1981.

12) Preber, H. and Bergström, J. : Effect of cigarette smoking on periodontal healing following surgical therapy. J. Clin. Periodontol., $17: 324-328$, 1990.

13) Ah, M.K.B., Johnson, G.K., Kaldahl, W.B., Patil, K.D. and Kalkwarf, K.L. : The effect of smoking on the response to periodontal therapy. J. Clin. Periodontol., 21 : 91-97, 1994.

14) Ismail, A.I., Burt, B.A. and Eklund, S.A. : Epidemiologic patterns of smoking and periodontal disease in the United States. JADA., 106: 617 $-621,1983$.

15) Bergström, J. and Eliasson, A. : Cigarette smoking and alveolar bone height in subjects with a high standard of oral higicnc. J. Clin. Periodontol., 14:466-469, 1987.

16) Bergström, J. : Cigarette smoking as risk factor in chronic periodontal disease. Commun. Dent. Oral Epidemiol., 17 :245-257, 1989.

17）鴨井久一，沼部幸博，佐藤 聡：歯周治療およびイ ンプラント治療と喫煙との関係. Quintessence Dental Implantology, 1:534-541, 1994.

18) Hanes, P.J., Schuster, G.S. and Lubas, S. : Binding, uptake, and release of nicotine by human gingival fibroblasts. J. Periodontol., 62 : 147-152, 1991.

19) Raulin, L.A., McPherson, J.C., McQuade, M.J., and Hanson, B.S. : The effect of nicotine on the attachment of human fibroblasts to glass and human root surfaces in vitro. J. Periodontol., 59 : 318-325, 1988.

20) Peacock, M.E., Sutherland, D.E., Schuster, G.S., Brennan, W.A., O'Neal, R.B., Strong, S.L. and Van Dyke, T.E. : The effect of nicotine on reproduction and attachement of human gingival fibroblasts in vitro. J. Periodontol., 64:658-665, 1993.

21) Tipton, D.A. and Kabbous, M.Kh. : Effects of nicotine on proliferation and extracellular matrix production of human gingival fibroblasts in vitro. J. Periodontol., 66 : 1056-1064, 1995.

22）大森みさき：歯周疾患に対する喫煙の影響に関する 研究, 第 2 報 喫煙前後の歯肉血流量の変化につい て, 歯学, 83:897-902, 1995.

23) Johnson, G.K., Fung. Y.K. and Squier, C.A. : Effects of systemic administration of nicotine on capillaries in rat oral mucosa. J. Oral Pathol. Med., 18:230-232, 1989.

24) Eichel, B., Shahrik, H.A. : Tobacco smoke toxicity : Loss of fuman oral leukocyte function and fluid-cell metabolism. Science, $166: 1424-1428$, 1969.

25) Bennet, K.R. and Reade, P.C. : Salivary immunoglobulin A Levels in normal subjects, tobacco smokers, and petients with minor aphthous ulceration. Oral Surg., 53:461-465, 1982.

26) Sweet, J.B. and Butler, D.P. : Effect of smoking on theincidence of localized osteitis following mandibular third molar surgery. Quintessence International, $2: 9-10,1978$.

27) Miller, P.D. Jr. : Rootcoverage with the free gingval graft: Factors associated with incomplete coverage. J. Periodontol., 58:674-681, 1987.

28) Bain, C.A. and Moy, P.K.: The association between the failure of dental implants and cigarertte smoking. Int. J. Oral Maxillofag. Implants., 8:609-615, 1993.

29) Tonetti, M.S., Pini-Prato, G. and Cortellini, P. : Effect of cigarette smoking on periodontal healing following GTR in infrabony defects. A preliminary retrospective study. J. Clin. Periodontol., 22 : 229-234, 1995.

連絡先：

日本歯科大学新潟歯学部歯周治療学教室

干 951 新潟市浜浦町 1-8 